\title{
The REFLO-STEMI trial comparing intracoronary adenosine, sodium nitroprusside and standard therapy for the attenuation of infarct size and microvascular obstruction during primary percutaneous coronary intervention: study protocol for a randomised controlled trial
}

Sheraz A Nazir ${ }^{1}$, Jamal N Khan', Islam Z Mahmoud², John P Greenwood ${ }^{3}$, Daniel J Blackman ${ }^{3}$, Vijay Kunadian ${ }^{4}$, Martin Been ${ }^{5}$, Keith R Abrams ${ }^{6}$, Robert Wilcox ${ }^{7}$, AA Jennifer Adgey ${ }^{8}$, Gerry P McCann ${ }^{1}$ and Anthony H Gershlick ${ }^{1 *}$

\begin{abstract}
Background: Microvascular obstruction (MVO) secondary to ischaemic-reperfusion injury is an important but underappreciated determinant of short- and longer-term outcome following percutaneous coronary intervention (PCI) treatment of ST-elevation myocardial infarction (STEMI). Several small studies have demonstrated a reduction in the degree of MVO utilising a variety of vasoactive agents, with adenosine and sodium nitroprusside (SNP) being most evaluated. However, the evidence base remains weak as the trials have had variable endpoints, differing drug doses and delivery. As such, the results regarding benefit are conflicting.

Methods: The REperfusion Facilitated by LOcal adjunctive therapy in STEMI (REFLO-STEMI) trial is a multicentre, prospective, randomised, controlled, open label, study with blinded endpoint analysis: Patients presenting within 6 $h$ of onset of STEMI and undergoing planned primary PCI (P-PCI) with TIMI 0/1 flow in the infarct-related artery (IRA) and no significant bystander coronary artery disease on angiography, are randomised into one of three groups: $\mathrm{PCl}$ with adjunctive pharmacotherapy (intracoronary adenosine or SNP) or control (standard PCI). All receive Bivalirudin anticoagulation and thrombus aspiration. The primary outcome is infarct size (IS) (determined as a percentage of total left ventricular mass) measured by cardiac magnetic resonance imaging (CMRI) undertaken at 48 to $72 \mathrm{~h}$ post $\mathrm{P}-\mathrm{PCl}$. Secondary outcome measures include MVO (hypoenhancement within infarct core) on CMRI, angiographic markers of microvascular perfusion and MACE during 1-month follow-up. The study aims to recruit 240 patients (powered at $80 \%$ to detect a $5 \%$ absolute reduction in IS).

(Continued on next page)
\end{abstract}

\footnotetext{
* Correspondence: agershlick@aol.com

'Department of Cardiovascular Sciences, University of Leicester and the NIHR Leicester Cardiovascular Biomedical Research Unit, Glenfield Hospital, Groby Road, LE3 9QP Leicester, UK

Full list of author information is available at the end of the article
} 


\begin{abstract}
(Continued from previous page)
Discussion: The REFLO-STEMI study has been designed to address the weaknesses of previous trials, which have collectively failed to demonstrate whether adjunctive pharmacotherapy with adenosine and/or SNP can reduce measures of myocardial injury (infarct size and MVO) and improve clinical outcome, despite good basic evidence that they have the potential to attenuate this process. The REFLO-STEMI study will be the most scientifically robust trial to date evaluating whether adjunctive therapy (intracoronary adenosine or SNP following thrombus aspiration) reduces CMRI measured IS and MVO in patients undergoing P-PCI within $6 \mathrm{~h}$ of onset of STEMI.
\end{abstract}

Trial registration: Trial registered 20th November 2012: ClinicalTrials.gov Identifier NCT01747174.

Keywords: Cardiovascular magnetic resonance, Myocardial infarction, Microvascular obstruction, Adenosine, Nitroprusside, Primary angioplasty

\section{Background}

Timely delivered primary percutaneous coronary intervention (P-PCI) has become the favoured reperfusion therapy for ST-elevation myocardial infarction (STEMI) in the US and Europe [1]. However, this interventional technique has not abolished the unpredictable phenomenon of no-reflow and the underappreciated, but potentially equally important, syndrome of normal epicardial-microvascular obstruction (MVO).

MVO describes abnormal tissue perfusion and/or coronary blood flow despite normal patency of the infarct-related artery (IRA) [2]. This can result in persistent myocardial injury and necrosis through interacting processes. Distal microembolisation of thrombus and plaque debris, activation of the inflammatory cascade, neutrophil plugging, toxic free-radical generation and capillary obstruction by intra-luminal (endothelial protrusion by cell swelling and cellular infiltrate rich in red-blood cells, platelets and granulocytes) and extra-luminal (compression from surrounding oedematous myocytes) mechanisms promote poor perfusion and irreversible injury to potentially viable myocytes [2-9]. These ultrastructural and functional changes result in a spectrum of MVO that, as detected by cardiac magnetic resonance imaging (CMRI), manifests in up to $70 \%$ of patients with STEMI treated with P-PCI [10-16]. Although the incidence of MVO varies between studies, presumably due to a combination of modifiable and nonmodifiable patient-related factors, its presence has been reported to be associated with major adverse cardiac event (MACE) rates of up to $30 \%$ at 1 month and $60 \%$ at 12 months [11].

Manual thrombectomy has been shown to improve angiographic microvascular flow irrespective of the presence of visible thrombus [17], and to reduce infarct size (IS) and preserve microvascular integrity assessed by CMRI [18], leading to improved left ventricular (LV) function and tissue perfusion assessed by myocardial contrast echocardiography (MCE) [19]. However, there is conflicting evidence as to whether this leads to overall improved clinical outcomes [20-26] although the large ongoing TOTAL trial will provide further insight [27].
Glycoprotein IIb/IIIa (GPIIbIIIa) inhibitors further reduce IS and improve markers of microvascular perfusion in STEMI patients undergoing P-PCI [28-30]. Bivaluridin has been shown in the ACUITY [31] and HORIZONS-AMI [32] trials to provide similar efficacy with less bleeding and even reduced mortality compared with unfractionated heparin plus GPIIb/IIIa receptor inhibitors in high-risk patients undergoing PCI. However, residual mortality and subsequent MACE rates suggest there is room for improvement even in those patients who do not demonstrate slow or no-reflow angiographically.

Basic understanding of the MVO process has led to the evolution of several treatment regimens designed to improve outcomes, and include the use of vasodilators [33-41], albeit mostly in clinical trials. Of these, sodium nitroprusside (SNP) [12,42-49] and adenosine [44,50-62] and their effect on attenuating or preventing MVO have been the most studied. The randomised controlled trials of adenosine and SNP in P-PCI are presented in Table 1 (Additional file 1). Adenosine, aside from being a potent vasodilator [63], may have additional benefits due to its pleiotropic effects: the anti-inflammatory action of adenosine is well recognised $[64,65]$ and its ability to block the neutrophil-mediated processes that promote MVO may explain the reduction of reperfusion injury seen with intracoronary (IC) adenosine in canine infarct models [66]. Similarly SNP, a direct nitric oxide (NO) donor that requires no intracellular metabolism [67], utilises NO's multiple vascular functions. These include vasodilatation of arterioles, inhibition of platelet adhesion and anti-inflammatory activity [68], which effectively reduce no-reflow in animal reperfusion-injury models $[69,70]$. SNP and adenosine have, in some trials, demonstrated favourable improvement in electrocardiographic (ECG) and angiographic markers of microvascular perfusion, as well as improvements in short-term MACE [42,44,55,71]. The randomised and placebo-controlled Acute Myocardial Infarction STudy of ADenosine (AMISTAD)-II trial sought to determine the benefit of adenosine in 2,118 patients presenting within $12 \mathrm{~h}$ of onset of anterior STEMI treated with thrombolysis (60\%) or P-PCI (40\%) [59]. IS and 
Table 1 Eligibility criteria

\begin{tabular}{ll}
\hline Inclusion criteria & Exclusion criteria \\
\hline - Aged $\geq 18$ years & - Contraindications to: P-PCl, CMRI, gadolinium-based and/or iodinated contrast \\
- Informed ASSENT (verbal consent) prior to angiography & agents, or study medications: Adenosine, SNP, Aspirin, Thienopyridine and Bivalirudin \\
- STEMI $\leq 6$ h of symptom onset, requiring P-PCl & - SBP $\leq 90 \mathrm{mmHg}$ \\
- Single-vessel coronary artery disease (non-culprit & - Cardiogenic shock \\
disease $<70 \%$ stenosis at angiography) & - Previous Q wave myocardial infarction \\
- TIMl flow 0/1 at angiography & - Culprit lesion not identified or located in a bypass graft \\
& - Stent thrombosis \\
- QTC $<450$ ms & - Left main disease \\
& - Known severe asthma \\
& - Known stage 4 or 5 chronic kidney disease (eGFR <30 mL/min $\left./ 1.73 \mathrm{~m}{ }^{2}\right)$
\end{tabular}

CMRI, cardiac magnetic resonance imaging; e-GFR, estimated glomerular filtration rate; $\mathrm{P}-\mathrm{PCl}$, primary percutaneous coronary intervention; SBP, systolic blood pressure; TIMI, Thrombolysis in Myocardial Infarction.

adverse clinical events were reduced in a sub-group who received a higher $(70 \mu \mathrm{g} / \mathrm{kg} / \mathrm{min})$ dose of adenosine and in those reperfused within $3 \mathrm{~h}$ of symptom onset. This trial, although the largest to date, has a number of limitations in addition to the mixed reperfusion strategy cohort: (1) Adenosine was administered by intravenous (IV) infusion after the PCI; (2) IS was measured relatively late after presentation in only $11 \%$ of patients and by technetium- $99 \mathrm{~m}$ sestamibi singlephoton emission computed tomography (SPECT), which may underestimate IS compared to CMRI; and (3) no measure of myocardial salvage was obtained. Overall, AMISTAD-II appears not to be applicable in the modern P-PCI era.

The effects of adenosine on the coronary microcirculation during STEMI have only been assessed using CMRI in one previous study. Desmet et al. [51] assessed whether intracoronary administration of adenosine, distal to the occlusion site and immediately before initial balloon inflation, resulted in increased myocardial salvage and decreased MVO versus placebo on CMR at 48 to $72 \mathrm{~h}$ post P-PCI in 112 patients. They reported no significant difference in myocardial salvage between the two groups (41.3\% vs. $47.8 \%, P=0.52$ ). MVO extent, angiographic markers of reperfusion and infarct size at 4 months were also similar in both groups. Interestingly, the authors reported a statistically significant benefit in favour of adenosine in patients with Thrombolysis in Myocardial Infarction (TIMI) 2-3 flow pre-PCI. This suggested that establishing flow prior to adenosine delivery was beneficial and perhaps necessary for the drug to have a clinical effect. As thrombectomy was not performed in this study, it is possible that adenosine may have been ineffective due to a combination of its short half-life and failure to reach the distal vascular bed. In addition, more patients had anterior MI in the adenosine group (48\% vs. $33 \%)$.
Anterior STEMI is known to be associated with larger ISs, reduced myocardial salvage and increased LV remodeling [72]. Moreover, the spontaneous reperfusion rate was high (28\%) in this study, evident as TIMI 2-3 flow prior to P-PCI. The placebo group had almost twice as many patients with established TIMI 2-3 flow prior to $\mathrm{PCI}$, and this is known to be associated with higher myocardial salvage and reduced IS. Finally, the expression of MVO indexed to the area at risk rather than IS or total LV mass has not been described previously in the evidence base and is unexplained in this study.

Although benefits have been shown for both adenosine and SNP in smaller trials, the results of such studies have been largely conflicting and hence, there is currently no consensus on the value of routine administration of adjunctive pharmaco-therapeutic agents to prevent or reduce MVO. In fact, a recent Cochrane review found that adenosine, when given as an adjunct during P-PCI, did not reduce all-cause mortality, non-fatal myocardial infarction or the incidence of angiographic no-reflow [73]. However, the authors conceded that the evidence base was limited and highlighted the need for further research with larger high quality trials. Heterogeneity in trial design (small numbers, sub-optimal drug dosages, inadequate anti-platelet therapy and variably chosen endpoints often lacking imaging confirmation of MVO and IS) has resulted in contradictory outcome data that may not be clinically applicable. Consequently there is divergent clinical practice, even within institutions. Furthermore, the incidence of no-reflow/MVO remains difficult to predict on coronary angiography alone. It could be argued that, given the strong relationship of MVO to prognosis, prophylactic prevention of MVO should be considered in all patients presenting with STEMI, irrespective of the thrombus burden, with delivery of agents theoretically able to reduce MVO. 
The failure of some previous randomised clinical trials to show a reduction in MVO may be in part related to factors other than clinical efficacy. The lack of a sensitive imaging modality to detect MVO and failure to deliver vasoactive agents close to the microvascular bed may potentially have reduced their therapeutic impact.

We therefore designed the REperfusion Facilitated by LOcal adjunctive therapy in STEMI (REFLO-STEMI) study to evaluate whether adjunctive adenosine or SNP, administered in two doses (the first optimally delivered by distal intracoronary (IC) injection following thrombectomy), would be effective in preventing MVO and reducing IS, as determined with the sensitive measure of CMRI, in patients undergoing P-PCI for STEMI.

\section{Methods}

The REFLO-STEMI trial is a multicentre, randomised, controlled, open label, clinical trial (see Figure 1) in four regional cardiac centres in the United Kingdom, conducted in compliance with the principles of the Helsinki Declaration. Ethical approval for the study (reference 11/H0405/ 10) was obtained from the National Research Ethics Service (UK). All patients presenting within $6 \mathrm{~h}$ of symptom onset of STEMI, who are suitable for reperfusion by P-PCI and have a baseline corrected QT interval (QTc) $<450 \mathrm{~ms}$ on admission ECG (to limit the risk from the possible QT prolongation effect of the study drugs), are provisionally eligible to participate in the study. TIMI flow grade $0-1$ in the IRA and no flow-limiting bystander disease (that is, no stenosis $\geq 70 \%$ in non-infarct-related arteries (N-IRA)) are pre-requisites to randomisation (see Table 1 for detailed eligibility criteria). Following verbal consent or assent [74,75] patients will be randomised 1:1:1 to: adjunctive IC adenosine, SNP or control (standard P-PCI alone) using a dedicated 24/7 computerised telephone service (provided by the 'Sealed Envelope Company', UK) with three stratifications: 1 , 'symptoms to balloon $<3 \mathrm{~h}$ or $\geq 3 \mathrm{~h}$ '; 2 , 'anterior infarction' or not; and 3 , recruiting centre.

In all cases, P-PCI will be performed in line with accepted practice with trans-radial or femoral arterial access using 6-7 Fr sheaths. Patients will be pre-treated with dual antiplatelet therapy with aspirin (300 mg loading dose and $75 \mathrm{mg} /$ day maintenance) and Prasugrel (60 mg loading dose and $10 \mathrm{mg} /$ day maintenance) [76,77] or Ticagrelor (loading dose $180 \mathrm{mg}$ and maintenance dose of $90 \mathrm{mg}$ twice daily) and given for up to 12 months [78-80]. Bivalirudin will be administered to all patients $(0.75 \mathrm{mg} / \mathrm{Kg}$ bolus plus infusion of $1.75 \mathrm{mg} / \mathrm{Kg} / \mathrm{hr})$ in the absence of specific contraindication, with dose reduction for renal insufficiency, and will be discontinued at the completion of P-PCI (but could be continued for $4 \mathrm{~h}$ if clinically indicated). For patients randomised to an intervention arm, following manual thrombectomy and thorough flushing of the catheter, the first drug dose (adenosine $1 \mathrm{mg}$ or SNP $250 \mathrm{mcg}$ ) will be injected as distally as possible via the thrombus aspiration catheter. Immediately following stent deployment, providing repeat measure of QTc is $<450 \mathrm{~ms}$ and remains $<60 \mathrm{~ms}$ increase over baseline value, the second drug dose (adenosine $1 \mathrm{mg}$ if IRA is the right coronary artery (RCA) otherwise $2 \mathrm{mg}$ or SNP $250 \mathrm{mcg}$ ) will be injected via the guide catheter. Administering the second drug dose distal to the stent was considered but the risk associated with crossing the stent with the thrombectomy catheter was thought to outweigh the benefit of distal drug delivery. The ECG will be recorded and retained at each angiography time point. The degree of ST-segment resolution (STR) will be determined from 12-lead ECGs acquired pre- and post-P-PCI and categorised as complete (>70\%), partial (30\% to $70 \%)$, or no $(<30 \%)$ STR $[16,81]$. The maximal sum of ST-segment elevation, measured $60 \mathrm{~ms}$ after the J point, will be calculated from three contiguous leads in the infarct territory. Angiographic images will be acquired at 30 frames per second with long acquisitions (to visualise the venous phase in contrast passage) in orthogonal views before intervention and after stenting (at the time of the final/optimal angiographic result) to enable determination of angiographic markers of MVO offline at a core laboratory (Newcastle University). TIMI myocardial perfusion grade (TMPG) will be assessed visually as previously described [82,83] (Additional file 1). Digital quantification of myocardial perfusion or 'blush' will be performed using 'QuBE' software [84]; corrected TIMI frame count (cTFC) will be calculated as the number of cine-frames needed for dye to reach standardised distal landmarks, to objectively evaluate coronary blood flow as a continuous variable $[85,86]$. A list of angiographic markers of MVO to be assessed is provided in Table 2 .

Following the P-PCI procedure, and when clinically stable, the patient will be provided with a detailed study information leaflet and written informed consent will be obtained from each participant to continue partaking in the trial. A 20\% drop out rate between P-PCI and CMR has been allowed for. Studies on informed consent in acute MI patients have suggested that oral information is far better received, processed and recalled by patients compared with the written form $[89,90]$. In the ISIS-4 patient cohort, $95 \%$ recalled receiving the oral information, whereas only $37 \%$ recalled receiving the written consent form [89]. Furthermore, only $18 \%$ of 346 patients prospectively studied reported reading the patient information sheet before providing or refusing consent to participate in the HERO-2 acute MI trial [90]. Of particular note is that patients who gave consent were more likely to report good or partial understanding of the written material than those who refused consent. This raises the possibility of selection bias at the time of consent. Consequently, we believe verbal explanation of a trial may be a more effective and valuable 


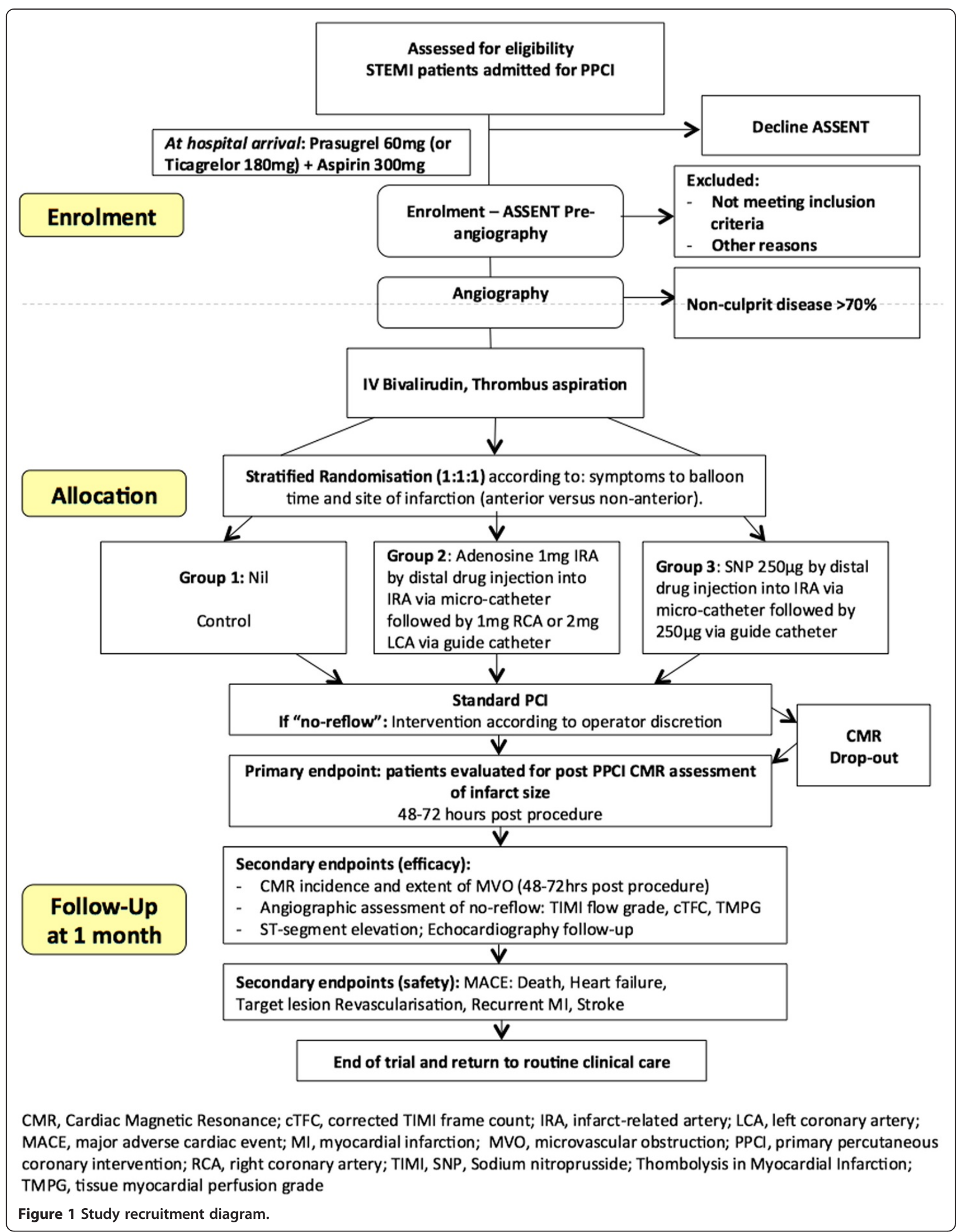


Table 2 Study outcome measures

\begin{tabular}{|c|c|}
\hline Type of outcome measure & Outcome measures \\
\hline \multirow[t]{5}{*}{ CMRI parameters } & - IS (\% total LV mass): Primary outcome \\
\hline & - Incidence and extent of MVO (\% LV mass) \\
\hline & - Myocardial salvage index (MSI) \\
\hline & - Intra-myocardial haemorrhage (IMH) \\
\hline & - LV ejection fraction (LVEF) and volumes \\
\hline \multirow[t]{6}{*}{ Angiographic markers of MVO } & • TIMI flow grade [87] \\
\hline & - Corrected TIMI frame count (cTFC) $[85,86]$ \\
\hline & - TIMI myocardial perfusion grade (TMPG) $[82,83,88]$ \\
\hline & - Computer-assisted myocardial blush quantification using the software 'Quantitative Blush Evaluator' (QuBE) [84] \\
\hline & - Incidence pre- and post-procedure of angiographic true 'no-reflow' \\
\hline & - Incidence of angiographic slow/no-reflow after P-PCl \\
\hline ECG & - Degree of ST segment resolution on ECG $[16,81]$ \\
\hline Echocardiography & - LV function at baseline and 3 months \\
\hline \multirow[t]{2}{*}{ Sub-analyses } & - Comparing CMRI markers with other myocardial perfusion markers (angiographic, ECG and cardiac enzymes) \\
\hline & - Overall MACE and its components at 1 month: death, need for TLR, recurrent Ml, severe heart failure and CVE \\
\hline
\end{tabular}

CMRI, cardiac magnetic resonance imaging; CVE, cerebrovascular event; ECG, electrocardiogram; e-GFR, estimated glomerular filtration rate; LV, left ventricular; LVEF, MACE, major adverse cardiac events; MI, myocardial infarction; MVO, microvascular obstruction; P-PCl, primary percutaneous coronary intervention; SBP, systolic blood pressure; TIMI, Thrombolysis in Myocardial Infarction; TLR, target lesion revascularisation.

source of information than a written consent form in the emergent situation of STEMI, where treatment must be provided without undue delay. This approach has been successfully used in two recent STEMI trials [74,75].

Blood samples will be drawn at baseline and at 4, 12 and $24 \mathrm{~h}$ after P-PCI for cardiac enzymes (CK-MB and Troponin) estimation and at pre-discharge for NTproBNP. ECG recording will be undertaken at $90 \mathrm{~min}$, $24 \mathrm{~h}$ and pre-discharge. All patients will be commenced on a beta-blocker, angiotensin converting enzyme (ACE) inhibitor and high-dose statin in addition to dual antiplatelet therapy, unless contra-indicated, according to international guidelines.

Patients will undergo CMRI at 48 to $72 \mathrm{~h}$ after presentation with STEMI on a $3.0 \mathrm{~T}$ scanner with retrospective electrocardiographic gating and dedicated cardiac receiver coils at each of the four participating centres (see Figure 2) to provide the primary endpoint $[91,92]$. Prior to contrast administration, T2-weighted short-tau inversion recovery (T2w-STIR) imaging with coil SI correction will be performed in long-axis (LAX) views and contiguous short-axis (SAX) slices covering the entire LV to assess for oedema (area at risk, (AAR)). Three SAX (base, mid and apical) tagged images will be acquired using a prospectively gated spatial modulation of magnetization (SPAMM) gradient-echo sequence. Early gadolinium enhancement (EGE) imaging will be acquired 1 to 3 min after $0.15 \mathrm{mmol} / \mathrm{kg}$ gadolinium-DTPA (Magnevist, Bayer, Germany) administration using a single-shot inversion-recovery gradient-echo sequence. Functional assessment of LV ejection fraction (LVEF), volumes and mass will be according to current standards with the use of a steady state free precession (SSFP) cine pulse sequence covering the whole LV with 8 to 12 contiguous short axis (SAX) slices. Late gadolinium enhancement (LGE) imaging [93] will then be performed in LAX (2-, 3 - and 4-chamber) views and contiguous SAX slices covering the whole LV. LGE images will be acquired 10 to 15 min post contrast using a segmented inversionrecovery gradient-echo sequence. The inversion time will be progressively adjusted to null unaffected myocardium. Study outcome measures are listed in Table 3.

CMRI analysis, blinded to patient details, will be undertaken in a central core lab (University of Leicester) using cmr42 (Circle Cardiovascular Imaging, Calgary, Canada). Anonymised CMR images will be graded for image quality using a 4 point scale before analysis: $4=$ excellent; $3=$ good; 2 =moderate; and 1 =non-analysable. Endocardial and epicardial borders will be manually contoured on contiguous SAX LV slices, excluding papillary muscles, trabeculae and blood-pool artefact for LV volumetric, AAR and IS analyses. Infarct will be identified as enhancement on LGE images and quantified using the Full-Width Half-Maximum (FWHM) technique [97]. MVO will be defined (and quantified) as hypoenhancement within infarcted myocardium, as determined from LGE images, and will be included in the total IS. Myocardial oedema will be quantified using semi-automatic thresholding defining AAR as enhancement within myocardium of signal intensity $>2$ standard deviations (SD) above that of a region of interest (ROI) contoured in remote myocardium. Hypoenhanced areas within the AAR will be 


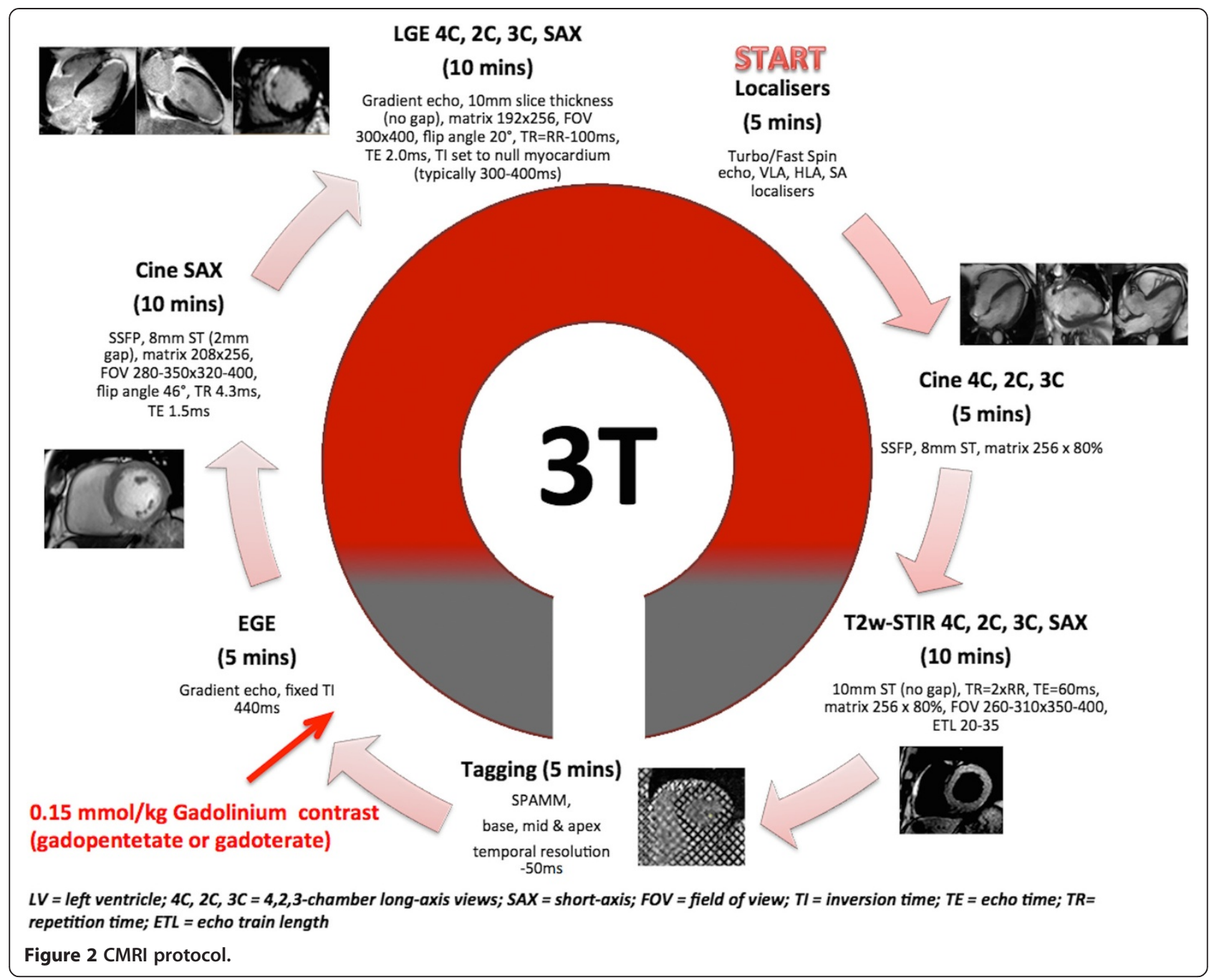

regarded as intra-myocardial haemorrhage (IMH). Myocardial salvage index (MSI) will be calculated as: 100* ((AAR-IS)/AAR). IS, MVO, AAR and IMH will be expressed as a percentage of LV end-diastolic mass (\% LVM) and LV volumes will be indexed to body-surface area. Intra- and inter-observer variability will be reported for the primary outcome measure.

All patients will be followed up for at least 1 month following randomisation and throughout the course of the study until the last patient recruited to the trial has completed 1-month follow-up. Median follow-up will be reported. Patients will also be flagged with the Office for National Statistics to ensure mortality data are captured. It is anticipated that most adverse events will be expected as recognised complications of STEMI or the revascularisation procedure. Such events will be recorded for the evaluation of outcome measures and for safety monitoring. Definitions of important adverse events are provided in Table 3. Investigators will be required to notify the coordinating centre (University Hospitals of Leicester,
UK) within $24 \mathrm{~h}$ if any of the following adverse events occur: death; a serious deterioration in a patient's health that results in life-threatening injury or illness; an event resulting in permanent impairment of a body structure or function; an event resulting in medical or surgical intervention to prevent permanent impairment to body structure or function; an event prolonging inpatient hospitalisation. On receipt of notification of any trial adverse or clinical event, the co-coordinating centre will request additional details specific to the nature of the event and carefully monitor these episodes overall. A clinical events committee has been established to review and adjudicate key trial adverse events, blinded to patient details and treatment allocation, using original source documents.

\section{Statistical methods}

Demographics will be presented and values of IS and MVO will be summarised, both overall and by treatment group. The distribution of IS will be investigated and the data will be transformed if found to be non-normally 
Table 3 Definitions of adverse events

\begin{tabular}{|c|c|}
\hline Adverse event & Definition \\
\hline Cardiogenic shock & $\begin{array}{l}\text { Systolic blood pressure }<90 \mathrm{mmHg} \text { for at least } 30 \mathrm{~min} \text { (or the need for supportive measures to maintain a } \\
\text { systolic blood pressure of }>90 \mathrm{mmHg} \text { ) in the presence of a heart rate of }>60 \mathrm{beat} / \mathrm{min} \text { in association with } \\
\text { signs of end-organ hypoperfusion (cold extremities, low urinary output }<30 \mathrm{~mL} / \mathrm{h} \text { and/or mental confusion) }\end{array}$ \\
\hline Myocardial infarction (MI) & $\begin{array}{l}\text { MI will be defined differently in specific clinical situations in this trial. The European Society of Cardiology (ESC) } \\
\text { and American College of Cardiology (ACC) criteria for acute, evolving or recent MI will apply }\end{array}$ \\
\hline Re-infarction & $\begin{array}{l}\text { Further chest pain during the index admission lasting }>20 \text { min accompanied by new electrocardiographic changes } \\
\text { (new Q waves }>0.04 \mathrm{~s} \text { or ST-segment elevation }>0.1 \mathrm{mV} \text { in two leads for }>30 \text { min), further enzyme rise or both }\end{array}$ \\
\hline Recurrent MI & $\begin{array}{l}\text { A } \geq 20 \% \text { rise in the value of the biomarker measured serially } 6 \text { to } 12 \mathrm{~h} \text { apart, provided the absolute value is greater } \\
\text { than the } 99 \% \text { percentile upper reference limit. For patients who die and for whom no cardiac markers were } \\
\text { obtained, the presence of new ST segment elevation and new chest pain would meet criteria for MI }\end{array}$ \\
\hline Contrast-induced nephropathy & $\begin{array}{l}25 \% \text { increase in serum creatinine concentration from the baseline value, or absolute increase of at least } 0.5 \mathrm{mg} / \mathrm{dL} \\
(44.2 \mathrm{~mol} / \mathrm{L}) \text {, appearing within } 48 \mathrm{~h} \text { of administration of contrast media, and maintained for } 2 \text { to } 5 \text { days [94-96] }\end{array}$ \\
\hline Cerebrovascular events & $\begin{array}{l}\text { Stroke is defined as a new focal neurological deficit of presumed vascular aetiology persisting }>24 \mathrm{~h} \text { combined } \\
\text { with a neurological imaging study that does not indicate a different aetiology. Transient ischaemic attack (TIA) is } \\
\text { any focal ischaemic neurological deficit of abrupt onset, which resolves completely within } 24 \mathrm{~h}\end{array}$ \\
\hline \multirow[t]{2}{*}{ Severe heart failure } & $\begin{array}{l}\text { Early heart failure: any new onset cardiogenic shock or heart failure occurring after randomisation and during } \\
\text { the index admission with radiographic evidence of pulmonary oedema requiring intravenous diuretic therapy }\end{array}$ \\
\hline & $\begin{array}{l}\text { Late heart failure: admission to hospital for treatment for documented New York Heart Association (NYHA) } \\
\text { class III or IV heart failure }\end{array}$ \\
\hline Major bleeding & $\begin{array}{l}\text { Defined according to the TIMI criteria as fatal bleeding, any intracranial bleeding or clinically overt signs of } \\
\text { haemorrhage associated with a drop in haemoglobin }(\mathrm{Hb}) \text { of } \geq 50 \mathrm{~g} / \mathrm{L}\end{array}$ \\
\hline
\end{tabular}

distributed. Primary analysis will be by intention to treat with a secondary analysis by treatment received. Patients entering into the study but not completing the CMRI will continue to be followed-up for MACE on an intention-to-treat basis. Analysis of Variance (ANOVA) will compare mean IS between groups. Each drug will be compared to the control (that is, Adenosine vs. Control and SNP vs. Control). Multivariable analysis using linear regression will take into consideration possible confounders such as sex, age and other co-morbidities. The major confounders of location of infarct (anterior/non-anterior) and time from symptom onset to reperfusion will be addressed by the stratified randomisation process. Other important confounders, such as collateral blood flow to the infarct territory determined by the Rentrop score [98], will be controlled for in the statistical analysis. Secondary endpoint analysis will employ time-to-event regression methods to investigate potentially important predictors of MACE.

\section{Sample size}

Sample size has been based on previous observations of significant correlation between the extent of CMR measured MVO and IS (which on average is $20 \%$ of LV mass as detected by CMR after P-PCI) [16]. Since there are no available data regarding the incidence of MVO with the study drugs assessed by CMR, and the wealth of published data on IS following P-PCI, we have chosen IS as the primary endpoint of the trial. IS is a powerful predictor of ventricular function, adverse LV remodeling and short-medium term clinical outcome $[13,15,16,99-111]$. Furthermore, new infarct size of $4 \%$ of
LV mass has been shown to be associated with adverse prognosis in patients with coronary artery disease undergoing revascularisation-related injury [112]. To detect a reduction in IS from $20 \%$ to $15 \%$ of LV mass, assuming a standard deviation of $10 \%$ [18,102,108,109,113-117], $\alpha$ of 0.05 , two-tailed, $80 \%$ power and a drop-out rate of $20 \%$ between P-PCI and CMR, 80 subjects per group (240 in total) will be required.

\section{Study organisation}

The study is funded by the Medical Research Council (MRC) and managed by the National Institute for Health Research (NIHR) on behalf of the MRC-NIHR partnership. The trial sponsor is the University Hospitals of Leicester NHS Trust. Trial support will be provided by the Leicester Clinical Trials Unit (UK Clinical Research Collaboration (UKCRC) ID 43) who will be responsible for database provision, data management and statistical analysis. The study will be overseen by a Trial Steering Committee (TSC), with an independent chair and two additional independent members, which will have access to the database after study completion and data-lock. Efficacy and safety data (particularly unexpected adverse events) will be scrutinised by an Independent Data and Safety Monitoring Board (DSMB), which will report back to the TSC. Clinical trials number NCT01747174 Clinicaltrials.gov.

\section{Discussion}

The REFLO-STEMI study has been designed to address the weaknesses of previous trials, which have collectively 
failed to demonstrate whether adjunctive pharmacotherapy with adenosine and/or SNP can reduce measures of myocardial injury (infarct size and MVO) and improve clinical outcome, despite good basic evidence that they have the potential to attenuate this process. The REFLOSTEMI trial will be the first study to combine what are considered appropriate efficacious drug dosages, delivered optimally to the site of maximal benefit, with the use of CMR to robustly measure reperfusion success, in a group of patients treated with a contemporary reperfusion strategy. The study will be powered accordingly to deliver a definitive answer as to whether these agents can reduce infarct size. Additional measures of myocardial perfusion (angiographic and electrocardiographic) and early clinical outcome data will provide further insight in to the potential role of prophylactic adjunctive pharmacotherapy, administered universally for STEMI patients or for those selected by retrospective analyses to most benefit, augmenting the benefits of timely-delivered P-PCI. As the largest and most scientifically robust trial to date, the REFLOSTEMI study, alongside the existing combination of studies, will inform future STEMI Guideline committees.

\section{Trial status}

The REFLO-STEMI trial has successfully completed recruitment of 247 patients. Follow-up and data collection are in progress and all investigators remain blinded to outcome data.

\section{Additional file}

Additional file 1: Table S1. Main randomised controlled trials investigating the role of adenosine and sodium nitroprusside (SNP) in attenuating or preventing MVO in STEMI treated with P-PCI $[42,44,45,51-53,55-57,60,61,118,119]$. Table S2. TIMI myocardial perfusion grade (TMPG) [82]. Table S3. TIMI flow grade (TFG) classification [87].

\footnotetext{
Abbreviations

AAR: Area at risk; ACC: American College of Cardiology; ACE: Angiotensin converting enzyme; ANOVA: Analysis of variance; CHF: Congestive heart failure; CK-MB: Creatine kinase MB isoenzyme; CMRI: Cardiac magnetic resonance imaging; CS: Cardiogenic shock; CTFC: Corrected TIMI frame count; CVD: Cardiovascular death; CVE: Cerebrovascular event; DSMB: Data and Safety Monitoring Board; ECG: Electrocardiogram; ESC: European Society of Cardiology; EGE: Early gadolinium enhancement; eGFR: Estimated glomerular filtration rate; FWHM: Full width half maximum; GPIIbllla: Glyocprotein IIbllla; Hs-CRP: High sensitivity C-reactive protein; IRA: Infarct-related artery; IC: Intra-coronary; IMH: Intra-myocardial haemorrhage; IS: Infarct size; LAX: Long axis; LBBB: Left bundle branch block; LCA: Left coronary artery; LGE: Late gadolinium enhancement; LV: Left ventricular; LVEDV: LV end-diastolic volume; LVEF: LV ejection fraction; LVM: LV end-diastolic mass; MACE: Major adverse cardiac events; MBG: Myocardial blush grade; MBV: Myocardial blood volume; MCE: Myocardial contrast echocardiography; MRC: Medical Research Council; MSI: Myocardial salvage index; MVD: Multi vessel disease; MVO: Microvascular obstruction; NIHR: National Institute for Health Research; N-IRA: Non-infarct related artery; NR: No-reflow; NT-proBNP: N-terminal pro-brain natriuretic peptide; NYHA: New York Heart Association; OS: Observational study; P-PCl: Primary percutaneous coronary intervention; RCA: Right coronary artery; ROI: Region of interest; SAX: Short axis; SBP: Systolic blood pressure; SD: Standard deviations; SNP: Sodium nitroprusside; SPAMM: Spatial modulation
}

of magnetisation; SSFP: Steady state free precession; STEMI: ST-elevation myocardial infarction; STD: ST-segment deviation; STR: ST-segment resolution; SPECT: Sestamibi single-photon emission computed tomography; T2W: T2-weighted; T2w-STIR: T2W short tau inversion recovery; TA: Thrombus aspiration; TIA: Transient ischaemic attack; TIMI: Thrombolysis in Myocardial Infarction; TFG: TIMI flow grade; TLR: Target lesion revascularisation; TMPG: TIMI myocardial perfusion grade; TSC: Trial Steering Committee; TVR: Target vessel revascularisation; UKCRC: United Kingdom Clinical Research Collaboration.

\section{Competing interests}

The authors declare that they have no competing interests.

\section{Authors' contributions}

AHG, IZM and GPM conceived the idea for the study. AHG, GPM, JPG, DB and IZM designed the study and developed protocols. AHG, GPM, IZM, JPG, DB and KRA prepared the funding application. SAN, JNK, JPG, DB, VK, MB and AHG are responsible for patient recruitment. SAN and GPM are responsible for all CMRI analyses. VK is responsible for analysing all angiograms. KRA will oversee all statistical analyses. RW chairs the TSC and AAJA chairs the DSMB. AHG, GPM, JPG, DB and KRA also have TSC membership. SAN drafted the manuscript. All authors read and approved the final manuscript.

\section{Acknowledgements}

The REFLO-STEMI trial is funded by the MRC and managed by the NIHR on behalf of the MRC-NIHR partnership. The study is sponsored by the University Hospitals of Leicester NHS Trust. GPM is supported by a NIHR postdoctoral fellowship. We also acknowledge the contribution of the following as TSC members (Prof Bob Wilcox (Chair), Dr Peter Ludman, Dr Jim Nolan, Mr Gerry Thompson (Lay member) and Dr David Hetmanski (Sponsor)) and DSMB members (Prof Jennifer Adgey (Chair), Dr lan BA Menown, Dr Mazhar Khan and Mr Cathal Walsh (statistics)).

\section{Author details}

'Department of Cardiovascular Sciences, University of Leicester and the NIHR Leicester Cardiovascular Biomedical Research Unit, Glenfield Hospital, Groby Road, LE3 9QP Leicester, UK. ²Department of Cardiovascular Imaging, Division of Imaging Sciences \& Biomedical Engineering, Rayne Institute, BHF Excellence Centre, St Thomas' Hospital, King's College London, London, UK.

${ }^{3}$ Multidisciplinary Cardiovascular Research Centre, Leeds Institute of Genetics, Health and Therapeutics, University of Leeds, Leeds, UK. ${ }^{4}$ Institute of Cellular Medicine, Faculty of Medical Sciences, Newcastle University and Cardiothoracic Centre, Freeman Hospital, Newcastle upon Tyne Hospitals NHS Foundation Trust, Newcastle upon Tyne, UK. ${ }^{5}$ Department of Cardiology, University Hospitals Coventry and Warwickshire NHS Trust, Coventry, UK ${ }^{6}$ Centre for Biostatistics \& Genetic Epidemiology, Department of Health Sciences, School of Medicine, University of Leicester, Leicester, UK. ${ }^{7}$ Faculty of Medicine \& Health Sciences, Queen's Medical Centre, Nottingham, UK. ${ }^{8}$ Heart Centre, Royal Victoria Hospital, Belfast, Northern Ireland, UK.

Received: 6 July 2014 Accepted: 10 September 2014

Published: 25 September 2014

\section{References}

1. Keeley EC, Boura JA, Grines CL: Primary angioplasty versus intravenous thrombolytic therapy for acute myocardial infarction: a quantitative review of 23 randomised trials. Lancet 2003, 361:13-20.

2. Kloner RA, Ganote CE, Jennings RB: The "no-reflow" phenomenon after temporary coronary occlusion in the dog. J Clin Invest 1974, 54:1496-1508.

3. Braunwald $\mathrm{E}$, Kloner RA: Myocardial reperfusion: a double-edged sword? J Clin Invest 1985, 76:1713-1719.

4. Harlan JM: Leukocyte-endothelial interactions. Blood 1985, 65:513-525.

5. McCord JM: Oxygen-derived free radicals in postischemic tissue injury. N Engl J Med 1985, 312:159-163.

6. Engler R, Covell JW: Granulocytes cause reperfusion ventricular dysfunction after 15-minute ischemia in the dog. Circ Res 1987, 61:20-28.

7. Topol EJ, Yadav JS: Recognition of the importance of embolization in atherosclerotic vascular disease. Circulation 2000, 101:570-580.

8. Gersh BJ: Optimal management of acute myocardial infarction at the dawn of the next millennium. Am Heart J 1999, 138:S188-S202.

9. Kotani J, Nanto S, Mintz GS, Kitakaze M, Ohara T, Morozumi T, Nagata S, Hori M: Plaque gruel of atheromatous coronary lesion may contribute to the 
no-reflow phenomenon in patients with acute coronary syndrome. Circulation 2002, 106:1672-1677.

10. Araszkiewicz A, Grajek S, Lesiak M, Prech M, Pyda M, Janus M, Cieslinski A: Effect of impaired myocardial reperfusion on left ventricular remodeling in patients with anterior wall acute myocardial infarction treated with primary coronary intervention. Am J Cardiol 2006, 98:725-728.

11. Galiuto L, Lombardo A, Maseri A, Santoro L, Porto I, Cianflone D, Rebuzzi AG, Crea F: Temporal evolution and functional outcome of no reflow: sustained and spontaneously reversible patterns following successful coronary recanalisation. Heart 2003, 89:731-737.

12. Rezkalla SH, Dharmashankar KC, Abdalrahman IB, Kloner RA: No-reflow phenomenon following percutaneous coronary intervention for acute myocardial infarction: incidence, outcome, and effect of pharmacologic therapy. J Interv Cardiol 2010, 23:429-436

13. Wu KC, Zerhouni EA, Judd RM, Lugo-Olivieri CH, Barouch LA, Schulman SP, Blumenthal RS, Lima JA: Prognostic significance of microvascular obstruction by magnetic resonance imaging in patients with acute myocardial infarction. Circulation 1998, 97:765-772.

14. Wu KC, Kim RJ, Bluemke DA, Rochitte CE, Zerhouni EA, Becker LC, Lima JA: Quantification and time course of microvascular obstruction by contrastenhanced echocardiography and magnetic resonance imaging following acute myocardial infarction and reperfusion. J Am Coll Cardiol 1998, 32:1756-1764

15. Hombach V, Grebe O, Merkle N, Waldenmaier S, Höher M, Kochs M, Wöhrle J, Kestler H: Sequelae of acute myocardial infarction regarding cardiac structure and function and their prognostic significance as assessed by magnetic resonance imaging. Eur Heart J 2005, 26:549-557.

16. Nijveldt R, Beek AM, Hirsch A, Stoel MG, Hofman MB, Umans VA, Algra PR, Twisk JW, van Rossum AC: Functional recovery after acute myocardial infarction: comparison between angiography, electrocardiography, and cardiovascular magnetic resonance measures of microvascular injury. J Am Coll Cardiol 2008, 52:181-189.

17. Vlaar PJ, Svilaas T, van der Horst IC, Diercks GF, Fokkema ML, de Smet BJ, van den Heuvel AF, Anthonio RL, Jessurun GA, Tan ES, Suurmeijer AJ, Zijlstra F: Cardiac death and reinfarction after 1 year in the Thrombus Aspiration during Percutaneous coronary intervention in Acute myocardial infarction Study (TAPAS): a 1-year follow-up study. Lancet 2008, 371:1915-1920.

18. Sardella G, Mancone M, Bucciarelli-Ducci C, Agati L, Scardala R, Carbone I, Francone M, Di Roma A, Benedetti G, Conti G, Fedele F: Thrombus aspiration during primary percutaneous coronary intervention improves myocardial reperfusion and reduces infarct size: the EXPIRA (thrombectomy with export catheter in infarct-related artery during primary percutaneous coronary intervention) prospective, randomized trial. J Am Coll Cardiol 2009, 53:309-315.

19. Liistro F, Grotti S, Angioli P, Falsini G, Ducci K, Baldassarre S, Sabini A, Brandini R, Capati E, Bolognese L: Impact of thrombus aspiration on myocardial tissue reperfusion and left ventricular functional recovery and remodeling after primary angioplasty. Circ Cardiovasc Interv 2009, 2:376-383.

20. Stone GW, Maehara A, Witzenbichler B, Godlewski J, Parise H, Dambrink J-HE, Ochala A, Carlton TW, Cristea E, Wolff SD, Brener SJ, Chowdhary S, El-Omar M, Neunteufl T, Metzger DC, Karwoski T, Dizon JM, Mehran R, Gibson CM; INFUSE-AMI Investigators: Intracoronary abciximab and aspiration thrombectomy in patients with large anterior myocardial infarction: the INFUSE-AMI randomized trial. JAMA 2012, 307:1817-1826.

21. Dudek D, Mielecki W, Burzotta F, Gasior M, Witkowski A, Horvath IG, Legutko J, Ochala A, Rubartelli P, Wojdyla RM, Siudak Z, Buchta P, Pregowski J, Aradi D, Machnik A, Hawranek M, Rakowski T, Dziewierz A, Zmudka K: Thrombus aspiration followed by direct stenting: a novel strategy of primary percutaneous coronary intervention in ST-segment elevation myocardial infarction. Results of the Polish-Italian-Hungarian RAndomized ThrombEctomy Trial (PIHRATE Trial). Am Heart J 2010, 160:966-972.

22. Frobert O, Lagerqvist B, Olivecrona GK, Omerovic E, Gudnason T, Maeng M, Aasa M, Angeras O, Calais F, Danielewicz M, Erlinge D, Hellsten L, Jensen U, Johannson AC, Karegren A, Nilsson J, Robertson L, Sandhall L, Sjogren I, Ostlund O, Harnek J, James SK, TASTE Trial: Thrombus aspiration during ST-segment elevation myocardial infarction. N Engl J Med 2013, 369:1587-1597.

23. Svilaas T, Vlaar PJ, van der Horst IC, Diercks GF, de Smet BJ, van den Heuvel AF, Anthonio RL, Jessurun GA, Tan ES, Suurmeijer AJ, Zijlstra F: Thrombus aspiration during primary percutaneous coronary intervention. $N$ Engl J Med 2008, 358:557-567.
24. Tomassini F, Gagnor A, Montali N, Gambino A, Bollati M, Infantino V, Rigattieri $S$, Varbella F: Impact of thrombus aspiration during primary percutaneous coronary intervention in cardiogenic shock complicating ST-segment elevation myocardial infarction. Cardiovasc Revasc Med 2013, 14:307-310.

25. Kumbhani DJ, Bavry AA, Desai MY, Bangalore S, Bhatt DL: Role of aspiration and mechanical thrombectomy in patients with acute myocardial infarction undergoing primary angioplasty: an updated meta-analysis of randomized trials. J Am Coll Cardiol 2013, 62:1409-1418.

26. De Luca G, Navarese EP, Suryapranata H: A meta-analytic overview of thrombectomy during primary angioplasty. Int J Cardiol 2013, 166:606-612.

27. Jolly SS, Cairns J, Yusuf S, Meeks B, Shestakovska O, Thabane L, Niemela K, Steg PG, Bertrand OF, Rao SV, Avezum A, Cantor WJ, Pancholy SB, Moreno R, Gershlick A, Bhindi R, Welsh RC, Cheema AN, Lavi S, Rokoss M, Dsavik V: Design and rationale of the TOTAL trial: a randomized trial of routine aspiration ThrOmbecTomy with percutaneous coronary intervention ( $\mathrm{PCl}$ ) versus $\mathrm{PCl}$ ALone in patients with ST-elevation myocardial infarction undergoing primary PCl. Am Heart J 2014, 167:315-321.

28. Thiele H, Schindler K, Friedenberger J, Eitel I, Fürnau G, Grebe E, Erbs S, Linke A, Möbius-Winkler S, Kivelitz D, Schuler G: Intracoronary compared with intravenous bolus abciximab application in patients with ST-elevation myocardial infarction undergoing primary percutaneous coronary intervention: the randomized Leipzig immediate percutaneous coronary intervention abciximab IV versus IC in ST-elevation myocardial infarction trial. Circulation 2008, 118:49-57.

29. Bartorelli AL, Trabattoni D, Galli S, Grancini L, Cozzi S, Ravagnani P: Successful dissolution of occlusive coronary thrombus with local administration of abciximab during PTCA. Catheter Cardiovasc Interv 1999, 48:211-213.

30. Kakkar AK, Moustapha A, Hanley HG, Weiss M, Caldito G, Misra P, Reddy PC, Tandon N: Comparison of intracoronary vs. intravenous administration of abciximab in coronary stenting. Catheter Cardiovasc Interv 2004, 61:31-34.

31. Stone GW, McLaurin BT, Cox DA, Bertrand ME, Lincoff AM, Moses JW, White HD, Pocock SJ, Ware JH, Feit F, Colombo A, Aylward PE, Cequier AR, Darius H, Desmet W, Ebrahimi R, Hamon M, Rasmussen LH, Rupprecht HJ, Hoekstra J, Mehran R, Ohman EM, ACUITY Investigators: Bivalirudin for patients with acute coronary syndromes. N Engl J Med 2006, 355:2203-2216.

32. Stone GW, Witzenbichler B, Guagliumi G, Peruga JZ, Brodie BR, Dudek D, Kornowski R, Hartmann F, Gersh BJ, Pocock SJ, Dangas G, Wong SC, Kirtane AJ, Parise H, Mehran R, HORIZONS-AMI Trial Investigators: Bivalirudin during primary PCl in acute myocardial infarction. N Engl J Med 2008, 358:2218-2230

33. Ishihara M, Sato H, Tateishi H, Kawagoe T, Shimatani Y, Kurisu S, Sakai K: Attenuation of the no-reflow phenomenon after coronary angioplasty for acute myocardial infarction with intracoronary papaverine. Am Heart J 1996, 132:959-963.

34. Kaplan BM, Benzuly KH, Kinn JW, Bowers TR, Tilli FV, Grines CL, O'Neill WW, Safian RD: Treatment of no-reflow in degenerated saphenous vein graft interventions: comparison of intracoronary verapamil and nitroglycerin. Cathet Cardiovasc Diagn 1996, 39:113-118.

35. Kloner RA, Alker KJ: The effect of streptokinase on intramyocardial hemorrhage, infarct size, and the no-reflow phenomenon during coronary reperfusion. Circulation 1984, 70:513-521.

36. Werner GS, Lang K, Kuehnert H, Figulla HR: Intracoronary verapamil for reversal of no-reflow during coronary angioplasty for acute myocardial infarction. Catheter Cardiovasc Interv 2002, 57:444-451.

37. Weyrens FJ, Mooney J, Lesser J, Mooney MR: Intracoronary diltiazem for microvascular spasm after interventional therapy. Am J Cardiol 1995, 75:849-850.

38. Rawitscher D, Levin TN, Cohen I, Feldman T: Rapid reversal of no-reflow using Abciximab after coronary device intervention. Cathet Cardiovasc Diagn 1997, 42:187-190.

39. Skelding KA, Goldstein JA, Mehta L, Pica MC, O'Neill WW: Resolution of refractory no-reflow with intracoronary epinephrine. Catheter Cardiovasc Interv 2002, 57:305-309.

40. Ota S, Nishikawa H, Takeuchi M, Nakajima K, Nakamura T, Okamoto S, Setsuda M, Makino K, Yamakado T, Nakano T: Impact of nicorandil to prevent reperfusion injury in patients with acute myocardial infarction: Sigmart Multicenter Angioplasty Revascularization Trial (SMART). Circ J 2006, 70:1099-1104.

41. Kunadian V, Zorkun C, Williams SP, Biller LH, Palmer AM, Ogando KJ, Lew ME, Nethala N, Gibson WJ, Marble SJ, Buros JL, Gibson CM: Intracoronary pharmacotherapy in the management of coronary microvascular dysfunction. J Thromb Thrombolysis 2008, 26:234-242. 
42. Amit G, Cafri C, Yaroslavtsev S, Fuchs S, Paltiel O, Abu-Ful A, Weinstein JM, Wolak A, llia R, Zahger D: Intracoronary nitroprusside for the prevention of the no-reflow phenomenon after primary percutaneous coronary intervention in acute myocardial infarction. A randomized, double-blind, placebo-controlled clinical trial. Am Heart J 2006, 152:887.e9-14.

43. Kobatake $R$, Sato $T$, Fujiwara $Y$, Sunami H, Yoshioka R, Ikeda T, Saito $H$, Ujihira T: Comparison of the effects of nitroprusside versus nicorandil on the slow/no-reflow phenomenon during coronary interventions for acute myocardial infarction. Heart Vessels 2011, 26:379-384.

44. Niccoli G, Rigattieri S, De Vita MR, Valgimigli M, Corvo P, Fabbiocchi F, Romagnoli E, De Caterina AR, La Torre G, Lo Schiavo P, Tarantino F, Ferrari R, Tomai F, Olivares P, Cosentino N, D'Amario D, Leone AM, Porto I, Burzotta F, Trani C, Crea F: Open-label, randomized, placebo-controlled evaluation of intracoronary adenosine or nitroprusside after thrombus aspiration during primary percutaneous coronary intervention for the prevention of microvascular obstruction in acute myocardial infarction: the REOPEN-AMI study (Intracoronary Nitroprusside Versus Adenosine in Acute Myocardial Infarction). JACC Cardiovasc Interv 2013, 6:580-589.

45. Parikh KH, Chag MC, Shah KJ, Shah UG, Baxi HA, Chandarana AH, Naik AM, Shah JN, Shah HD, Goyal RK: Intracoronary boluses of adenosine and sodium nitroprusside in combination reverses slow/no-reflow during angioplasty: a clinical scenario of ischemic preconditioning. Can J Physiol Pharmacol 2007, 85:476-482.

46. Pasceri V, Pristipino C, Pelliccia F, Granatelli A, Speciale G, Roncella A, Pironi B, Capasso M, Richichi G: Effects of the nitric oxide donor nitroprusside on no-reflow phenomenon during coronary interventions for acute myocardial infarction. Am J Cardiol 2005, 95:1358-1361.

47. Shinozaki N, Ichinose $H$, Yahikozawa K, Shimada H, Hoshino K: Selective intracoronary administration of nitroprusside before balloon dilatation prevents slow reflow during percutaneous coronary intervention in patients with acute myocardial infarction. Int Heart J 2007, 48:423-433.

48. Wang HJ, Lo PH, Lin JJ, Lee H, Hung JS: Treatment of slow/no-reflow phenomenon with intracoronary nitroprusside injection in primary coronary intervention for acute myocardial infarction. Catheter Cardiovasc Interv 2004, 63:171-176.

49. Youssef AA, Wu CJ, Hang CL, Cheng $\mathrm{Cl}$, Yang $\mathrm{CH}$, Chen $\mathrm{CJ}$, Chen $\mathrm{YH}$, Chai HT, Chua S, Yeh KH, Yip HK: Impact of PercuSurge device conjugative with intracoronary administration of nitroprusside on no-reflow phenomenon following primary percutaneous coronary intervention. Circ J 2006, 70:1538-1542.

50. Claeys MJ, Bosmans J, De Ceuninck M, Beunis A, Vergauwen W, Vorlat A, Vrints CJ: Effect of intracoronary adenosine infusion during coronary intervention on myocardial reperfusion injury in patients with acute myocardial infarction. Am J Cardiol 2004, 94:9-13.

51. Desmet W, Bogaert J, Dubois C, Sinnaeve P, Adriaenssens T, Pappas C, Ganame J, Dymarkowski S, Janssens S, Belmans A, Van de Werf F: High-dose intracoronary adenosine for myocardial salvage in patients with acute ST-segment elevation myocardial infarction. Eur Heart J 2011, 32:867-877.

52. Fokkema ML, Vlaar PJ, Vogelzang M, Gu YL, Kampinga MA, de Smet BJ, Jessurun GA, Anthonio RL, van den Heuvel AF, Tan ES, Zijlstra F: Effect of high-dose intracoronary adenosine administration during primary percutaneous coronary intervention in acute myocardial infarction: a randomized controlled trial. Circ Cardiovasc Interv 2009, 2:323-329.

53. Grygier M, Araszkiewicz A, Lesiak M, Janus M, Kowal J, Skorupski W, Pyda M, Mitkowski P, Grajek S: New method of intracoronary adenosine injection to prevent microvascular reperfusion injury in patients with acute myocardial infarction undergoing percutaneous coronary intervention. Am J Cardiol 2011, 107:1131-1135.

54. Mahaffey KW, Puma JA, Barbagelata NA, DiCarli MF, Leesar MA, Browne KF, Eisenberg PR, Bolli R, Casas AC, Molina-Viamonte V, Orlandi C, Blevins R, Gibbons RJ, Califf RM, Granger CB: Adenosine as an adjunct to thrombolytic therapy for acute myocardial infarction: results of a multicenter, randomized, placebo-controlled trial: the Acute Myocardial Infarction STudy of ADenosine (AMISTAD) trial. J Am Coll Cardiol 1999, 34:1711-1720.

55. Marzilli M, Orsini E, Marraccini P, Testa R: Beneficial effects of intracoronary adenosine as an adjunct to primary angioplasty in acute myocardial infarction. Circulation 2000, 101:2154-2159.

56. Micari A, Belcik TA, Balcells EA, Powers E, Wei K, Kaul S, Lindner JR: Improvement in microvascular reflow and reduction of infarct size with adenosine in patients undergoing primary coronary stenting. Am J Cardiol 2005, 96:1410-1415.
57. Petronio AS, De Carlo M, Ciabatti N, Amoroso G, Limbruno U, Palagi C, Di Bello V, Romano MF, Mariani M: Left ventricular remodeling after primary coronary angioplasty in patients treated with abciximab or intracoronary adenosine. Am Heart J 2005, 150:1015.

58. Quintana M, Hjemdahl P, Sollevi A, Kahan T, Edner M, Rehnqvist N, Swahn E, Kjerr AC, Nasman P: Left ventricular function and cardiovascular events following adjuvant therapy with adenosine in acute myocardial infarction treated with thrombolysis, results of the ATTenuation by Adenosine of Cardiac Complications (ATTACC) study. Eur J Clin Pharmacol 2003, 59:1-9.

59. Ross AM, Gibbons RJ, Stone GW, Kloner RA, Alexander RW: A randomized, double-blinded, placebo-controlled multicenter trial of adenosine as an adjunct to reperfusion in the treatment of acute myocardial infarction (AMISTAD-II). J Am Coll Cardiol 2005, 45:1775-1780.

60. Stoel MG, Marques KM, de Cock CC, Bronzwaer JG, von Birgelen C, Zijlstra F: High dose adenosine for suboptimal myocardial reperfusion after primary PCl: A randomized placebo-controlled pilot study. Catheter Cardiovasc Interv 2008, 71:283-289.

61. Zhang H, Tian NL, Hu ZY, Wang F, Chen L, Zhang YJ, Chen SL: Three hours continuous injection of adenosine improved left ventricular function and infarct size in patients with ST-segment elevation myocardial infarction. Chin Med J (Engl) 2012, 125:1713-1719.

62. Vijayalakshmi K, Whittaker VJ, Kunadian B, Graham J, Wright RA, Hall JA, Sutton A, de Belder MA: Prospective, randomised, controlled trial to study the effect of intracoronary injection of verapamil and adenosine on coronary blood flow during percutaneous coronary intervention in patients with acute coronary syndromes. Heart 2006, 92:1278-1284.

63. Berne RM: The role of adenosine in the regulation of coronary blood flow. Circ Res 1980, 47:807-813.

64. Ernst PB, Garrison JC, Thompson LF: Much ado about adenosine: adenosine synthesis and function in regulatory $T$ cell biology. J Immunol 2010, 185:1993-1998.

65. Linden J: Molecular approach to adenosine receptors: receptor-mediated mechanisms of tissue protection. Annu Rev Pharmacol Toxicol 2001, 41:775-787.

66. Olafsson B, Forman MB, Puett DW, Pou A, Cates CU, Friesinger GC, Virmani $R$ : Reduction of reperfusion injury in the canine preparation by intracoronary adenosine: importance of the endothelium and the no-reflow phenomenon. Circulation 1987, 76:1135-1145.

67. Bates JN, Baker MT, Guerra R Jr, Harrison DGDG: Nitric oxide generation from nitroprusside by vascular tissue. Evidence that reduction of the nitroprusside anion and cyanide loss are required. Biochem Pharmacol 1991, 42(Suppl):S157-S165.

68. Gavin JB, Maxwell L, Edgar SG: Microvascular involvement in cardiac pathology. J Mol Cell Cardiol 1998, 30:2531-2540.

69. Pemberton M, Anderson GL, Barker JH: Characterization of microvascular vasoconstriction following ischemia/reperfusion in skeletal muscle using videomicroscopy. Microsurgery 1996, 17:9-16.

70. Wang WZ, Anderson G, Fleming JT, Peter FW, Franken RJ, Acland RD, Barker $\mathrm{J}$ : Lack of nitric oxide contributes to vasospasm during ischemia/ reperfusion injury. Plast Reconstr Surg 1997, 99:1099-1108.

71. Kloner RA, Forman MB, Gibbons RJ, Ross AM, Alexander RW, Stone GW: Impact of time to therapy and reperfusion modality on the efficacy of adenosine in acute myocardial infarction: the AMISTAD-2 trial. Eur Heart $J$ 2006, 27:2400-2405.

72. Masci PG, Ganame J, Francone M, Desmet W, Lorenzoni V, lacucci I, Barison A, Carbone I, Lombardi M, Agati L, Janssens S, Bogaert J: Relationship between location and size of myocardial infarction and their reciprocal influences on post-infarction left ventricular remodelling. Eur Heart J 2011, 32:1640-1648.

73. Aung Naing K, Li L, Su Q, Wu T: Adenosine and verapamil for no-reflow during primary percutaneous coronary intervention in people with acute myocardial infarction. Cochrane Database Syst Rev 2013, 6:CD009503.

74. Kelly DJ, McCann GP, Blackman D, Curzen NP, Dalby M, Greenwood JP, Fairbrother K, Shipley L, Kelion A, Heatherington S, Khan JN, Nazir S, Alahmar A, Flather M, Swanton H, Schofield P, Gunning M, Hall R, Gershlick AH: Complete Versus culprit-Lesion only PRimary PCI Trial (CVLPRIT): a multicentre trial testing management strategies when multivessel disease is detected at the time of primary $\mathrm{PCl}$ : rationale and design. Eurolntervention 2013, 8:1190-1198.

75. Armstrong PW, Gershlick AH, Goldstein P, Wilcox R, Danays T, Lambert Y, Sulimov V, Rosell Ortiz F, Ostojic M, Welsh RC, Carvalho AC, Nanas J, Arntz HR, 
Halvorsen S, Huber K, Grajek S, Fresco C, Bluhmki E, Regelin A, Vandenberghe K, Bogaerts K, Van de Werf F, STREAM Investigative Team: Fibrinolysis or primary $\mathrm{PCl}$ in ST-segment elevation myocardial infarction. N Engl J Med 2013, 368:1379-1387.

76. Wiviott SD, Braunwald E, McCabe CH, Montalescot G, Ruzyllo W, Gottlieb S, Neumann FJ, Ardissino D, De Servi S, Murphy SA, Riesmeyer J, Weerakkody G, Gibson CM, Antman EM, TRITON-TIMI 38 Investigators: Prasugrel versus clopidogrel in patients with acute coronary syndromes. N Engl J Med 2007, 357:2001-2015.

77. National Institute for Health and Care Excellence: Prasugrel for the treatment of acute coronary syndromes with percutaneous coronary intervention. London: NICE; 2009. http://www.nice.org.uk/guidance/ta182.

78. James S, Akerblom A, Cannon CP, Emanuelsson H, Husted S, Katus H, Skene A, Steg PG, Storey RF, Harrington R, Becker R, Wallentin L: Comparison of ticagrelor, the first reversible oral $\mathrm{P} 2 \mathrm{Y}(12)$ receptor antagonist, with clopidogrel in patients with acute coronary syndromes: Rationale, design, and baseline characteristics of the PLATelet inhibition and patient Outcomes (PLATO) trial. Am Heart J 2009, 157:599-605.

79. European Society of Cardiology: ESC Guidelines for the management of acute myocardial infarction in patients presenting with ST-segment elevation. Sophia Antipolis: ESC; 2009. http://www.escardio.org/guidelines-surveys/escguidelines/GuidelinesDocuments/Guidelines_AMI_STEMI.pdf 2012 (accessed 15th January 2014).

80. National Institute for Health and Care Excellence: Acute coronary syndromes ticagrelor: guidance. London: NICE; 2011. http://www.nice.org.uk/guidance/ ta236.

81. Schroder R, Dissmann R, Bruggemann T, Wegscheider K, Linderer T, Tebbe $U$, Neuhaus KL: Extent of early ST segment elevation resolution: a simple but strong predictor of outcome in patients with acute myocardial infarction. J Am Coll Cardiol 1994, 24:384-391.

82. Gibson CM, Cannon CP, Murphy SA, Ryan KA, Mesley R, Marble SJ, McCabe $\mathrm{CH}$, Van De Werf F, Braunwald E: Relationship of TIMI myocardial perfusion grade to mortality after administration of thrombolytic drugs. Circulation 2000, 101:125-130.

83. Gibson CM, Cannon CP, Murphy SA, Marble SJ, Barron HV, Braunwald E: Relationship of the TIMI myocardial perfusion grades, flow grades, frame count, and percutaneous coronary intervention to long-term outcomes after thrombolytic administration in acute myocardial infarction. Circulation 2002, 105:1909-1913.

84. Vogelzang M, Vlaar PJ, Svilaas T, Amo D, Nijsten MW, Zijlstra F: Computerassisted myocardial blush quantification after percutaneous coronary angioplasty for acute myocardial infarction: a substudy from the TAPAS trial. Eur Heart J 2009, 30:594-599.

85. Gibson CM, Cannon CP, Daley WL, Dodge JT Jr, Alexander B Jr, Marble SJ, McCabe CH, Raymond L, Fortin T, Poole WK, Braunwald E: TIMI frame count: a quantitative method of assessing coronary artery flow. Circulation 1996, 93:879-888.

86. Kunadian V, Harrigan C, Zorkun C, Palmer AM, Ogando K, Biller LH, Lord EE, Williams SP, Lew ME, Ciaglo LN, Buros JL, Marble SJ, Gibson WJ, Gibson CM: Use of the TIMI frame count in the assessment of coronary artery blood flow and microvascular function over the past 15 years. J Thromb Thrombolysis 2009, 27:316-328.

87. Collaborators TIMI: The Thrombolysis in Myocardial Infarction (TIMI) trial. Phase I findings. TIMI Study Group. N Engl J Med 1985, 312:932-936.

88. van't Hof AW, Liem A, Suryapranata H, Hoorntje JC, de Boer MJ, Zijlstra F: Angiographic assessment of myocardial reperfusion in patients treated with primary angioplasty for acute myocardial infarction: myocardial blush grade. Zwolle Myocardial Infarction Study Group. Circulation 1998, 97:2302-2306.

89. Yuval R, Halon DA, Merdler A, Khader N, Karkabi B, Uziel K, Lewis BS: Patient comprehension and reaction to participating in a double-blind randomized clinical trial (ISIS-4) in acute myocardial infarction. Arch Intern Med 2000, 160:1142-1146.

90. Williams BF, French JK, White HD, HERO-2 consent substudy investigators: Informed consent during the clinical emergency of acute myocardial infarction (HERO-2 consent substudy): a prospective observational study. Lancet 2003, 361:918-922.

91. Ibrahim T, Hackl T, Nekolla SG, Breuer M, Feldmair M, Schömig A: Acute myocardial infarction: serial cardiac MR imaging shows a decrease in delayed enhancement of the myocardium during the 1st week after reperfusion. Radiology 2010, 254:88-97.
92. Albert TSE, Kim RJ, Judd RM: Assessment of no-reflow regions using cardiac MRI. Basic Res Cardiol 2006, 101:383-390.

93. Tilak GS, Hsu LY, Hoyt RF Jr, Arai AE, Aletras AH: In vivo T2-weighted magnetic resonance imaging can accurately determine the ischemic area at risk for 2-day-old nonreperfused myocardial infarction. Invest Radiol 2008, 43:7-15.

94. Reed MD, Bell D: Clinical pharmacology of bivalirudin. Pharmacotherapy 2002, 22:105S-111S.

95. Cortese B, Picchi A, Micheli A, Limbruno U: Intracoronary bivalirudin for no reflow reversal: a second chance to treat this disorder? J Thromb Thrombolysis 2009, 28:74-76.

96. Bertomeu-Gonzalez V, Bodi V, Sanchis J, Nunez J, Lopez-Lereu MP, Pena G, Losada A, Gomez C, Chorro FJ, Llacer A: [Limitations of myocardial blush grade in the evaluation of myocardial perfusion in patients with acute myocardial infarction and TIMI grade 3 flow]. Rev Esp Cardiol 2006, 59:575-581.

97. Flett AS, Hasleton J, Cook C, Hausenloy D, Quarta G, Ariti C, Muthurangu V Moon JC: Evaluation of techniques for the quantification of myocardial scar of differing etiology using cardiac magnetic resonance. JACC Cardiovasc Imaging 2011, 4:150-156.

98. Rentrop KP, Cohen M, Blanke H, Phillips RA: Changes in collateral channel filling immediately after controlled coronary artery occlusion by an angioplasty balloon in human subjects. J Am Coll Cardiol 1985, 5:587-592.

99. Bello D, Einhorn A, Kaushal R, Kenchaiah S, Raney A, Fieno D, Narula J, Goldberger J, Shivkumar K, Subacius H, Kadish A: Cardiac magnetic resonance imaging: infarct size is an independent predictor of mortality in patients with coronary artery disease. Magn Reson Imaging 2011, 29:50-56.

100. Eitel I, Desch S, de Waha S, Fuernau G, Gutberlet M, Schuler G, Thiele H: Long-term prognostic value of myocardial salvage assessed by cardiovascular magnetic resonance in acute reperfused myocardial infarction. Heart 2011, 97:2038-2045.

101. Ezekowitz JA, Armstrong PW, Granger CB, Theroux P, Stebbins A, Kim RJ, Patel MR: Predicting chronic left ventricular dysfunction 90 days after ST-segment elevation myocardial infarction: An Assessment of Pexelizumab in Acute Myocardial Infarction (APEX-AMI) Substudy. Am Heart J 2010, 160:272-278.

102. Ganame J, Messalli G, Dymarkowski S, Rademakers FE, Desmet W, Van de Werf F, Bogaert J: Impact of myocardial haemorrhage on left ventricular function and remodelling in patients with reperfused acute myocardial infarction. Eur Heart J 2009, 30:1440-1449.

103. Gerber BL: Accuracy of contrast-enhanced magnetic resonance imaging in predicting improvement of regional myocardial function in patients after acute myocardial infarction. Circulation 2002, 106:1083-1089.

104. Kelle S, Roes SD, Klein C, Kokocinski T, de Roos A, Fleck E, Bax JJ, Nagel E: Prognostic value of myocardial infarct size and contractile reserve using magnetic resonance imaging. J Am Coll Cardiol 2009, 54:1770-1777.

105. Klem I, Shah DJ, White RD, Pennell DJ, van Rossum AC, Regenfus M, Sechtem U, Schvartzman PR, Hunold P, Croisille P, Parker M, Judd RM, Kim $\mathrm{RJ}$ : Prognostic value of routine cardiac magnetic resonance assessment of left ventricular ejection fraction and myocardial damage: an international, multicenter study. Circ Cardiovasc Imaging 2011, 4:610-619.

106. Kwong RY, Chan AK, Brown KA, Chan CW, Reynolds HG, Tsang S, Davis RB: Impact of unrecognized myocardial scar detected by cardiac magnetic resonance imaging on event-free survival in patients presenting with signs or symptoms of coronary artery disease. Circulation 2006, 113:2733-2743.

107. Larose E, Rodes-Cabau J, Pibarot P, Rinfret S, Proulx G, Nguyen CM, Dery JP, Gleeton O, Roy L, Noel B, Barbeau G, Rouleau J, Boudreault JR, Amyot M, De Larochelliere R, Bertrand OF: Predicting late myocardial recovery and outcomes in the early hours of ST-segment elevation myocardial infarction traditional measures compared with microvascular obstruction, salvaged myocardium, and necrosis characteristics by cardiovascular magnetic resonance. J Am Coll Cardiol 2010, 55:2459-2469.

108. Lund GK, Stork A, Muellerleile K, Bansmann MP, Schlichting U, Mu M, Adam G, Meinertz T: Prediction of left ventricular remodeling and analysis of infarct resorption in patients with reperfused myocardial infarcts by using contrast-enhanced MR imaging. Radiology 2007, 245:95-104.

109. Wu E, Ortiz JT, Tejedor P, Lee DC, Kansal P, Carr JC, Holly TA, Klocke FJ, Bonow $\mathrm{RO}$ : Infarct size by contrast enhanced cardiac magnetic resonance is a stronger predictor of outcomes than left ventricular ejection fraction or end-systolic volume index: prospective cohort study. Heart 2008, 94:730-736.

110. Lonborg J, Vejlstrup N, Kelbaek H, Holmvang L, Jorgensen E, Helqvist S, Saunamaki K, Ahtarovski KA, Botker HE, Kim WY, Clemmensen P, Engstrom 
T: Final infarct size measured by cardiovascular magnetic resonance in patients with ST elevation myocardial infarction predicts long-term clinical outcome: an observational study. Eur Heart J Cardiovasc Imaging 2013, 14:387-395.

111. Izquierdo M, Ruiz-Granell R, Bonanad C, Chaustre F, Gomez C, Ferrero A, Lopez-Lereu P, Monmeneu JV, Nunez J, Chorro FJ, Bodi V: Value of early cardiovascular magnetic resonance for the prediction of adverse arrhythmic cardiac events after a first noncomplicated ST-segmentelevation myocardial infarction. Circ Cardiovasc Imaging 2013, 6:755-761.

112. Rahimi K, Banning AP, Cheng ASH, Pegg TJ, Karamitsos TD, Channon KM, Darby S, Taggart DP, Neubauer S, Selvanayagam JB: Prognostic value of coronary revascularisation-related myocardial injury: a cardiac magnetic resonance imaging study. Heart 2009, 95:1937-1943.

113. Nijveldt R, Beek AM, Hofman MB, Umans VA, Algra PR, Spreeuwenberg MD, Visser CA, van Rossum AC: Late gadolinium-enhanced cardiovascular magnetic resonance evaluation of infarct size and microvascular obstruction in optimally treated patients after acute myocardial infarction. J Cardiovasc Magn Reson 2007, 9:765-770.

114. Beek AM, Nijveldt R, van Rossum AC: Intramyocardial hemorrhage and microvascular obstruction after primary percutaneous coronary intervention. Int J Cardiovasc Imaging 2010, 26:49-55.

115. Masci PG, Ganame J, Strata E, Desmet W, Aquaro GD, Dymarkowski S, Valenti V, Janssens S, Lombardi M, Van de Werf F, L'Abbate A, Bogaert J: Myocardial salvage by CMR correlates with LV remodeling and early ST-segment resolution in acute myocardial infarction. JACC CardiovasC Imaging 2010, 3:45-51.

116. Hahn J-Y, Song YB, Gwon H-C, Choe YH, Kim JH, Sung J, Choi S-H, Choi JH, Kim DK, Hong KP, Park JE, Lee SH: Relation of left ventricular infarct transmurality and infarct size after primary percutaneous coronary angioplasty to time from symptom onset to balloon inflation. Am J Cardiol 2008, 102:1163-1169.

117. Nijveldt R, van der Vleuten P, Hirsch A, Beek AM, Tio R, Tijssen JGP, Piek JJ, van Rossum AC, Zijlstra F: Early electrocardiographic findings and MR imaging-verified microvascular injury and myocardial infarct size. JACC Cardiovasc Imaging 2009, 2:1187-1194.

118. Zhao YJ, Fu XH, Ma XX, Wang DY, Dong QL, Wang YB, Li W, Xing K, Gu XS, Jiang YF: Intracoronary fixed dose of nitroprusside via thrombus aspiration catheter for the prevention of the no-reflow phenomenon following primary percutaneous coronary intervention in acute myocardial infarction. Exp Ther Med 2013, 6:479-484

119. Pan W, Wang LF, Yu JH, Fan Y, Yang SS, Zhou L, Li Y, Li WM: Intracoronary nitroprusside in the prevention of the no-reflow phenomenon in acute myocardial infarction. Chin Med J (Engl) 2009, 122:2718-2723.

\section{doi:10.1186/1745-6215-15-371}

Cite this article as: Nazir et al.: The REFLO-STEMI trial comparing

intracoronary adenosine, sodium nitroprusside and standard therapy for the attenuation of infarct size and microvascular obstruction during primary percutaneous coronary intervention: study protocol for a randomised controlled trial. Trials 2014 15:371.

\section{Submit your next manuscript to BioMed Central and take full advantage of:}

- Convenient online submission

- Thorough peer review

- No space constraints or color figure charges

- Immediate publication on acceptance

- Inclusion in PubMed, CAS, Scopus and Google Scholar

- Research which is freely available for redistribution

Submit your manuscript at www.biomedcentral.com/submit 